\title{
Minimum Wages and Youth Employment: Evidence from the Finnish Retail Trade Sector
}

\author{
Petri Böckerman and Roope Uusitalo
}

\begin{abstract}
Following an agreement between the trade unions and the employer organizations in 1993, Finnish employers could temporarily pay less than the existing minimum wage for young workers. We examine the effects of these minimum wage exceptions by comparing the changes in wages and employment of the groups whose minimum wages were reduced with simultaneous changes among slightly older workers for whom the minimum wages remained unchanged. Our analysis is based on payroll record data and minimum wage agreements from the retail trade sector. The results show that average wages in the eligible group declined only modestly. We find no significant effects on employment.
\end{abstract}

\section{Introduction}

The negative employment effects of minimum wages were taken for granted for decades (e.g. Brown et al. 1982). Only in the 1990s was this consensus view challenged when several studies based on natural experiments demonstrated that minimum wage increases often had no negative employment effects and sometimes the effects were even positive (Card and Krueger 1995). However, considerable debate about the relevance of the new view remains (Dolado et al. 1996; Neumark and Wascher 2007).

This paper evaluates the effects of minimum wages on youth wages and employment in Finland. The analysis is based on a union agreement that allowed employers to pay less than the existing minimum wage to new workers who were below 25 years of age. This subminimum youth wage policy was effective between 1993 and 1995. The policy intended to boost employment among the groups that were most likely to be affected by high

Petri Böckerman is at the Labour Institute for Economic Research. Roope Uusitalo is at the Government Institute for Economic Research (VATT) and Institute for Labour Market Policy Evaluation (IFAU). 
minimum wages. We examine the effects of the policy by comparing the changes in wages and employment of the group whose minimum wages were reduced with simultaneous changes among slightly older workers for whom the minimum wages remained unchanged.

The Finnish case is of broader interest for two reasons. First, Finland belongs to a group of countries where wage distribution is narrow and wage rigidity is relatively high (Dickens et al. 2007). For example, OECD (2006a) argues that high minimum wages contribute to a shortage of low-skilled service jobs in Finland. Their suggestion to Finland and other countries with a similar wage structure is to increase flexibility in wage setting by introducing a lower youth minimum wage (OECD 2006b: 88). Second, the youth subminimum wage policy was temporary which allows us to examine both the effects of a decrease and the effects of a subsequent increase in the minimum wage. This helps to account for the pre-existing trends in the employment shares and enables us to construct a simple specification test based on a comparison of the period before the minimum wage cuts were implemented and the period after these temporary reductions were removed. Naturally, it is not clear that the effects of a temporary change are similar to a change that is permanent. We return to this question in the conclusions and compare our results with experimental evidence that has considered the effect of temporary changes in minimum wages (Falk et al. 2006).

Finland does not have statutory minimum wage laws. Instead, minimum wages are determined separately in each industry in the contracts between the unions and the employer organizations. These contracts are extended to all workers in each sector and are therefore also binding for non-union workers. The union contracts specify a set of task-specific minimum wages. In addition to varying across sectors, these minimum provisions vary across regions and seniority. The Finnish minimum wage system closely resembles the Swedish and Norwegian systems (Skedinger 2006, 2008). Union bargaining over minimum wages is not uncommon elsewhere either. For example, the seven EU countries that do not have statutory minimum wages have all established a tradition of minimum wages set by collective bargaining, often at the industry level. Even in countries with statutory minimum wages, the social partners often have a direct or a consultative role in minimum wage adjustments (Eurofound 2007).

Variation in union-negotiated minimum wages across worker groups is useful because the changes in the minimum wage that only affect some workers help in identifying the effects of the minimum wages. Despite this, the evidence is sparse. Out of 86 minimum wage studies cited in a survey by Neumark and Wascher (2007), only Skedinger (2006) analyses the effects of union-negotiated minimum wages.

Variation in minimum wage across worker groups has not been exploited by previous Finnish research either, and not much is known about the effects of minimum wages. Sauramo and Solttila (1985) use time-series data and explain youth employment shares with the ratio of minimum and average wages at the industry level. They find no effects of minimum wages on youth 
employment. Saari (1996) interviewed 150 employers asking questions about the same youth subminimum wage policy that we analyse in this paper. $\mathrm{He}$ discovered that only two of the employers interviewed had paid less than the usual minimum wage and concluded that the minimum wage exceptions did not have any significant effect on employers' hiring decisions.

The Finnish setting also has other useful features for analysing the effects of minimum wages. Incomplete compliance, which has been a problem in several studies, is not a major issue in Finland, where the unions are sufficiently strong to monitor and to enforce minimum wage regulations. Also, measurement errors are a smaller problem in our study since we use payroll record data from the employers' association rather than self-reported earnings from household surveys.

We focus on the retail trade sector because it is a prominent low-wage industry in Finland, and therefore, an industry where one could expect to discover the employment effects of minimum wages. In addition to being a low-wage industry, the retail trade sector has a very high worker turnover rate ( 45 per cent per year for workers younger than 30 years of age) and a high share of part-time workers (50 per cent) allowing employers to adjust their workforce and hours per worker quickly.

The rest of the paper is structured as follows. Section 2 describes the institutions and the structure of minimum wages. Section 3 explains the minimum wage exceptions. Section 4 introduces the data. Section 5 contains empirical analyses. Section 6 concludes.

\section{Finnish labour relations and minimum wages}

\section{Description of Institutions}

Wage bargaining in Finland involves a high degree of co-ordination between the unions and the employer organizations. A framework agreement is typically negotiated at a national level between the union and employer federations on a one- or two-year basis. After central agreement has been reached, the individual unions and the respective employer organizations bargain over wages separately in each industry. These contracts determine a general wage increase applied to all wages in a sector and a wage schedule determining minimum pay in each task. The industry-specific collective labour agreements are also binding for non-union members in industries where the union contract is 'representative'. This is assessed by a specific institution, the Board for Ratification of the Validity of Collective Agreements. It has considered a contract to be representative when at least half the workers in the industry are union members. Since union density is currently around 70 per cent, most industries have a representative contract and the coverage of collective agreements is among the highest in the OECD countries (Layard and Nickell 1999).

In the retail trade sector, union density has declined recently but it was still 67 per cent in 1995 (Böckerman and Uusitalo 2006: 292). Minimum wages in 
the retail trade are based on collective agreements between the Service Union United (PAM) and the Federation of Finnish Commerce. They determine the lowest possible wage for each task in the sector. Employers can naturally pay more than the minimum and the average wages are generally higher than the minimum rates. The minimum conditions cannot be repealed by the conduct of local negotiations.

\section{The Structure of Minimum Wages in the Retail Trade Sector}

Task-specific minimum wages vary by region, the job-complexity level and the worker's experience. The collective agreements specify wages separately in three geographical regions and aim to compensate for the regional differences in the cost of living. Minimum wages are highest in the Helsinki metropolitan area (cost-of-living index region I) and lower in the cost-ofliving index regions II and III. The cost-of-living classification is mainly based on the 1980 price-level estimates by Statistics Finland. These estimates attempted to capture regional differences in commodity prices and housing costs (Lehtonen et al. 1983). Even though these price-level estimates are obviously out of date, the classification has proved to be hard to change partly because certain social benefits are tied to the cost-of-living classification.

Minimum wages also depend on the job-complexity level and experience. In retail trade contracts there are six different job-complexity levels and four different experience levels (first, third, fifth and eighth year seniority increment) that determine minimum wages. These seniority increments are also based on work experience in the retail trade sector, not only on tenure in the current firm.

\section{Minimum wage exceptions}

The Finnish economy went through a severe recession in the early 1990s (e.g. Honkapohja and Koskela 1999). Real GDP fell by 14 per cent in the years 1990-1993. The unemployment rate increased to almost 17 per cent from an average of around 5 per cent during the 1980s, which caused substantial pressures to increase flexibility in wage formation.

Because of these macroeconomic difficulties, the right-wing government that was in power between 1991 and 1995 threatened to create new legislation to relax the minimum wage regulations for young workers in order to improve their employment opportunities. To avoid legislative regulation and government involvement in wage bargaining, the trade unions made an agreement with the employer organizations. According to the union agreement, the minimum wages of young workers aged below 25 were reduced for two years. There were minor differences in the exact content and the conditions of the exceptions between different sectors because the agreements were negotiated separately for each industry. The agreement for the retail trade 
sector was signed on 7 June 1993. It was in force between 15 June 1993 and 15 June $1995 .{ }^{1}$

Based on this agreement, the minimum wages of workers younger than 25 were reduced to 80 per cent of the lowest task- and region-specific tariffs during their first year in the retail trade sector. The trainee wage was reduced from 85 to 60 per cent of the lowest minimum wage prevailing in each region.

It is useful to note that educational opportunities and other policies that might affect youth employment were almost unchanged during the recession years. The level of earnings-related unemployment benefits was slightly reduced in 1992-1993 but the change applied to all age groups. A more significant change that tightened eligibility for unemployment benefits for persons under 25 was implemented only in 1997.

\section{Data}

Our data come from the payroll records of the Finnish employers' association. The data cover all workers in all firms that are members of the association. All major retail trade chains and most large independent retailers are members of the employers' association. Smaller shops typically do not belong to the association. Therefore, the members of the association are clearly not a representative sample of all retail trade employers. On the other hand, the workers covered by the data seem quite similar to those in the whole sector. For example, the age distribution of the workers in the data is almost identical to the age distribution in the whole retail trade as reported in the Labour Force Survey. Overall, roughly half of all workers in the retail trade sector are covered by the data.

The data provide information about monthly wages, weekly working time, and some information about workers' individual characteristics such as age, gender and education. Information originates directly from the firms' pay systems. The data are detailed enough to identify all the factors that have an effect on the minimum wages for each person. This is quite natural since one of the main purposes of collecting the data is to monitor wage growth after the union contract has been agreed upon. The data cover the situation during one month of each year (August before 1995 and October in and after 1995).

The monthly wage concept that we use includes the base wage and all personal and task-specific bonuses as well as shift work, and evening and Sunday bonuses but excludes performance-based payments, commissions and profit-sharing. Hours are recorded as regular weekly working time. Task-specific minimum wages are collected from the collective agreements of the retail trade sector for each year and then linked to the payroll record data by using information on region, the job-complexity level and the worker's experience. Since minimum wages are defined on a monthly basis, we construct a monthly wage also for part-time workers using the explicit formula that is stated in the collective agreements (full-time equivalent monthly wage $=$ part-time worker's wage $\times(37.5 /$ part-time worker's weekly working hours)). 
About 80 per cent of the workers in our data are women. Seventy-five per cent have only had compulsory education. Half of the persons are part-time workers (i.e. they work regularly, at most, 34 hours per week). The average weekly working time is around 30 hours. A significant fraction of the workers in the retail trade sector are students, which partly explains high turnover rates (Ilmakunnas and Maliranta 2003). Unfortunately, the data do not contain any indicators that would allow calculating their exact share. Descriptive statistics for the sample that we use are reported in the Appendix (Table A1).

In order to obtain a relatively homogeneous sample, we focus on two main occupational groups in the retail trade sector, which both consist of salespersons. Most of the workers ( 94 per cent) in our data belong to the group of salespersons whose work does not require special professional expertise. A typical worker in the data is employed at the cash register in one of the retail business chains. Minimum wages are defined separately for these two groups in each year and they depend on region, the job-complexity level and the worker's experience, as explained earlier. To avoid problems in defining the minimum rates for those who hold multiple jobs, we use information on the salespersons that have only one job (during the one-month interval of the data). After imposing these restrictions the data contain information on between 30,000 and 50,000 persons per year.

\section{The effects of minimum wages}

\section{Shaping the Wage Distribution}

Figure 1 shows the effect of minimum wages on wage distribution. We have plotted the differences between actual nominal monthly wages and the minimum monthly wages stipulated in the collective agreements in each task for the years 1991, ${ }^{2} 1995,2000$ and 2005. There is a clear spike in the wage distribution at the minimum rate and missing mass below that point.

Two additional points are worth noting. First, most of the workers receive wages that are not much above the minimum wages. ${ }^{3}$ Second, the share of subminimum wages is rather low. Only 5 per cent of workers receive wages below the minimum wage and even these are likely to be mostly due to measurement error in working hours. For a comparison, Skedinger (2006: 271) reports that one tenth of actual wages are below the minimum wage in Sweden. In both cases, the share of subminimum wages in the payroll record data is significantly lower than in household surveys (e.g. Stewart and Swaffield 2002).

\section{The 'Bite' of Minimum Wages}

Figure 2 plots the ratio of minimum wages to average wages and shows that the minimum wages were somewhat more binding during the recession in the 


\section{British Journal of Industrial Relations}

FIGURE 1

The Differences (Per cent) between Actual Wages and Task-Specific Minimum Wages.
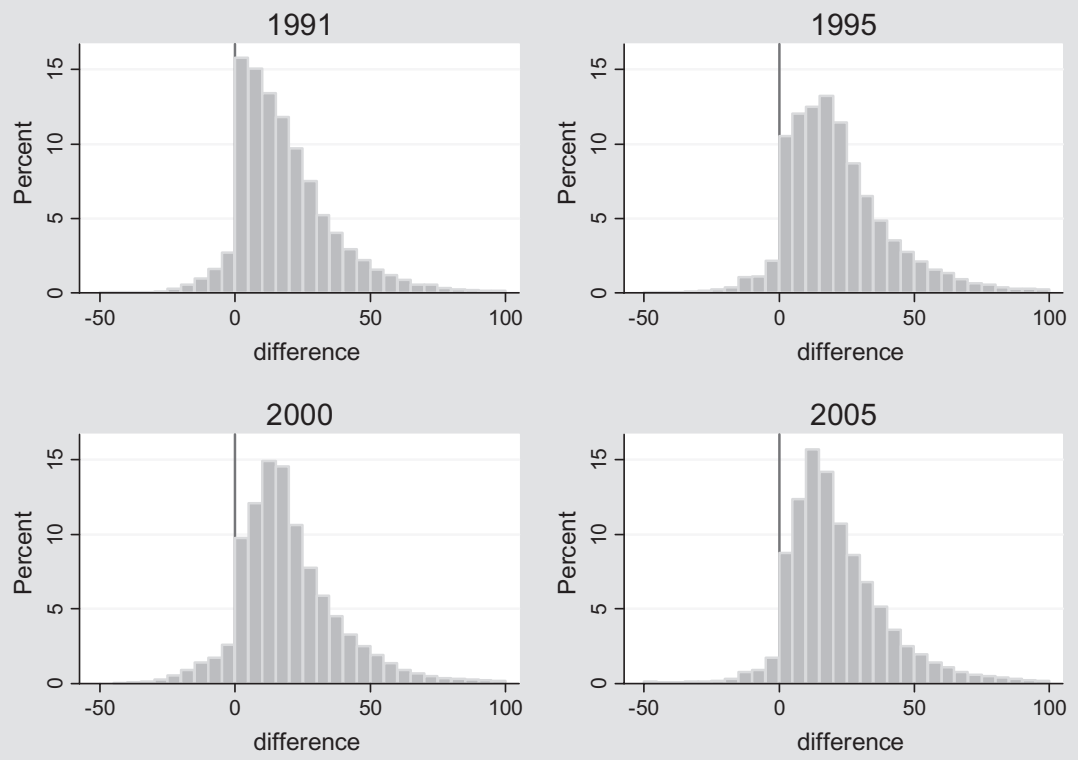

Note: The vertical line is at zero.

FIGURE 2

The Ratio of Minimum Wages to Average Wages.

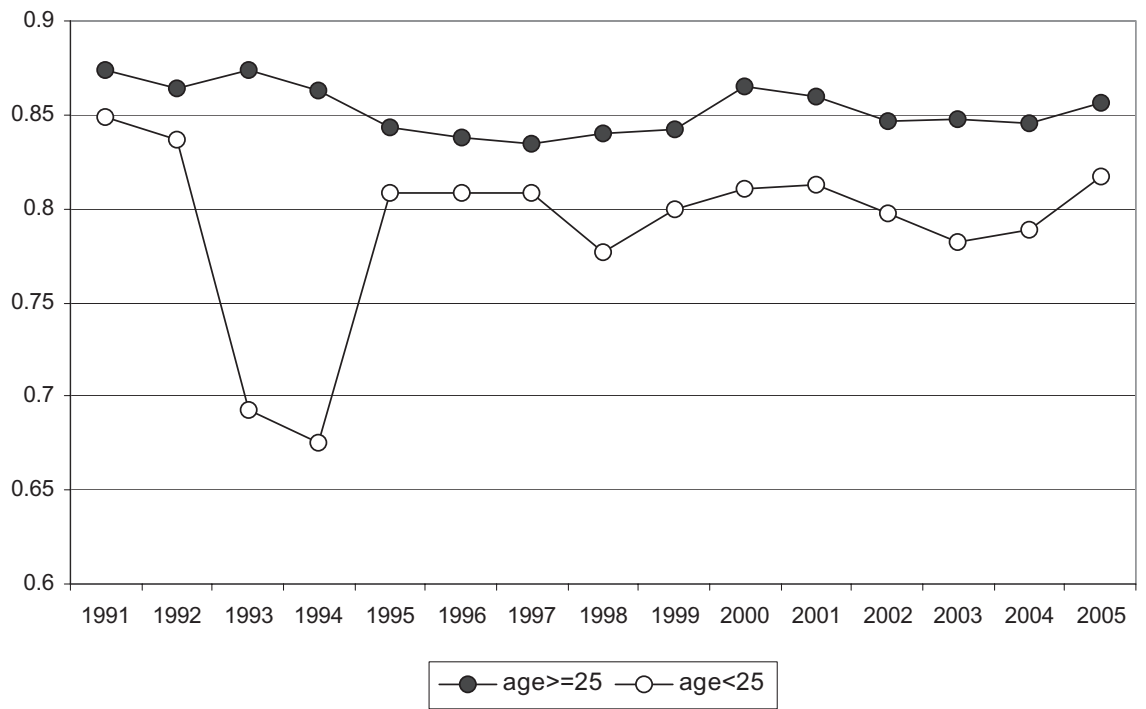

(C) Blackwell Publishing Ltd/London School of Economics 2009. 
early 1990s. The 'bite' of minimum wages tends to be weaker for the youngest workers, because the minimum wages are lower for young workers who have less experience than older workers. This pattern is not necessarily common in the countries with statutory minimum wage legislation that specifies a single minimum rate. The ratio of minimum wages to average wages for workers below 25 also declined drastically in 1993-1994, owing to the reduced minimum wages schemes during the years of exceptions. ${ }^{4}$ This already suggests that the cut in the minimum wage did not substantially reduce average wages.

\section{Effects on Wages and Employment}

We analyse the effects of minimum wage exceptions by comparing the changes in wages and employment of the groups whose minimum wages were reduced to simultaneous changes among slightly older workers for whom the old minimum wage was still binding. We focus on the years 1991-1996, covering the period from two years before the youth minimum wage exceptions were implemented to two years after the exceptions were removed. We restrict the data to workers below the age of 30 with a maximum of two years' work experience to obtain a control group that would be as close a substitute as possible to two treatment groups (workers below the age of 25 and trainees) that were eligible for minimum wage exceptions in 1993-1994. ${ }^{5}$

We report the levels and changes in wages among the control and the two treatment groups in Table 1. The first nine cells in the top left-hand corner report the average log wages in the period before (1991-1992), during (19931994) and after (1995-1996) the minimum wage exceptions. In the top righthand corner, we report the changes in wages when minimum wage exceptions were introduced in 1993 ('During-Before') and the changes in wages when these exceptions were removed in 1995 ('After-During'). We calculate these changes separately in the two treatment groups (workers below the age of 25 and trainees) and in the control group (workers aged 25-30). In the bottom right-hand corner we report the differences in these changes that capture the effect of introducing and removing the minimum wage exceptions on average wages. These differences-in-differences estimates are based on a simple regression model where wages are explained with the treatment group status, time dummies and their interactions:

$$
\begin{aligned}
\log w_{i}= & \beta_{0}+\beta_{1} D(\text { Age }<25)+\beta_{2} D(\text { Trainee })+\beta_{3} D(\text { During })+\beta_{4} D(\text { After }) \\
& +\beta_{5} D(\text { Age }<25) \times D(\text { During })+\beta_{6} D(\text { Trainee }) \times D(\text { During }) \\
& +\beta_{7} D(\text { Age }<25) \times D(\text { After })+\beta_{8} D(\text { Trainee }) \times D(\text { After })+\varepsilon_{i}
\end{aligned}
$$

In equation (1), the parameter $\beta_{5}$ measures the effect of minimum wage cut among the workers below 25 and $\beta_{6}$ captures the effect on the trainees. To estimate the effects of removing the minimum wage exceptions in 1995, we simply modify the specification so that the reference period is 1993-1994.

According to our estimates, the decrease in the minimum wage decreased average wages among the young workers by 1 per cent compared with the

(C) Blackwell Publishing Ltd/London School of Economics 2009. 


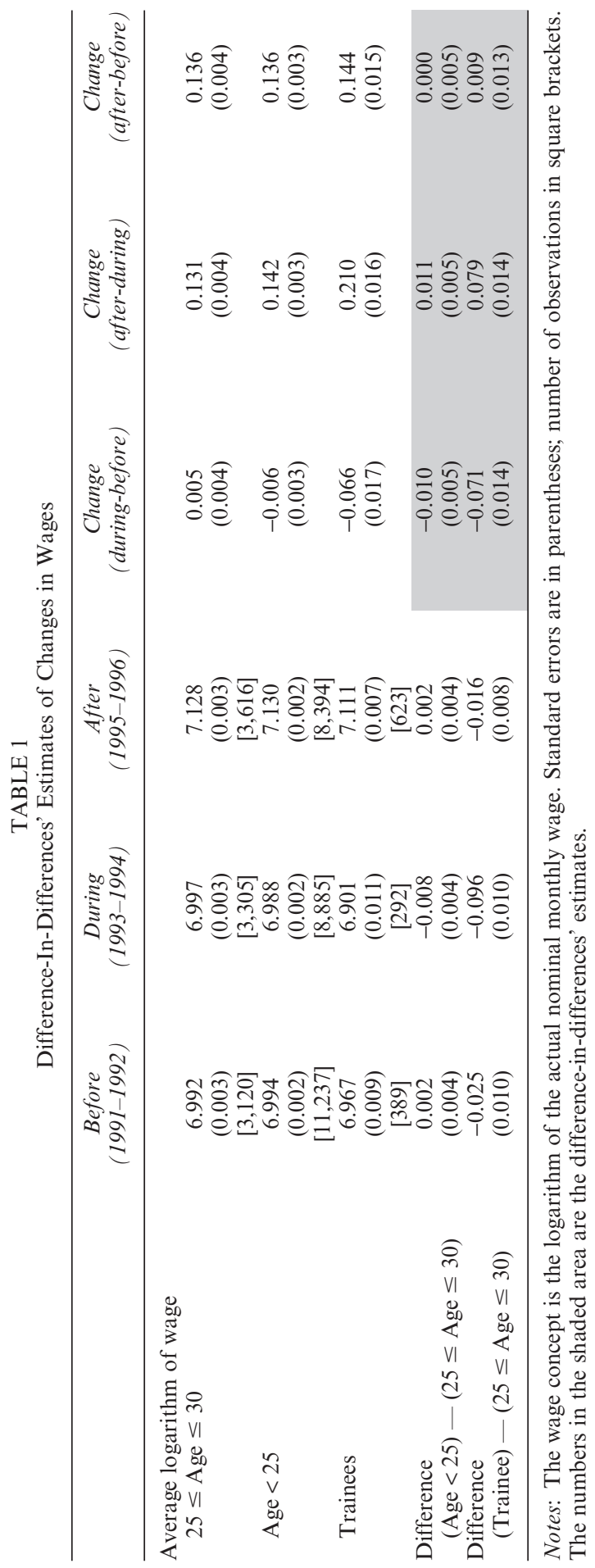

(C) Blackwell Publishing Ltd/London School of Economics 2009. 
older control group. Similarly, the removal of the minimum wage exceptions also increased wages by 1 per cent compared with the control group. Because the sample size is large, even these small effects are statistically significant. The effects are larger for trainees. The trainee wage decreased by 7 per cent more than the control group wage after the introduction of the minimum wage exceptions and increased by 8 per cent more after their removal. In the column furthest right, we report the differences in wages between the period before the minimum wage exceptions (1991-1992) and the period after their removal (1995-1996). These estimates can be regarded as a specification test for the model. Significantly different changes over this period would imply that there had been different trends in the treatment and the control groups. However, our estimates in the last column are very close to zero, which adds confidence to the estimates for wage changes in the previous two columns.

To check the robustness of our results, we first added several covariates to equation (1) (gender, indicator for part-time workers, education, retail trade chain and region). We also calculated the effects separately for the new recruits, defined as those who are not observed in the retail trade data in the previous year. These specifications do not change our baseline results much. The effect of the introduction of the minimum wage exceptions on the young workers' wages is always in the range between 0.5 and 1 per cent. The estimated standard errors are larger, especially in the models for the new recruits. The effect of the introduction of the exceptions also remain rather similar when we narrow the treatment group to those aged below 25 with, at most, one year's recorded work experience or define the control group in slightly different ways. The effect of removing minimum wage exceptions is less robust particularly if we include also those with 1-2 years of experience in the control group but include only those with, at most, one year of experience in the treatment group. In these cases, we also detect trends in relative wages. This finding may indicate problems related to seasonal effects, as discussed later. Experiments with quantile regression models revealed that the effect on wages was almost entirely due to effects at the lowest decile. ${ }^{6}$

To examine the employment effects of the minimum wage exceptions, we aggregate the data to the firm level. Now we do not restrict the data to workers below 30 , but instead calculate the employment shares and the share of hours worked by the workers in the treatment and the control groups in each firm. Otherwise, our difference-in-differences estimates for employment effects are similar to earlier estimates for wage effects.

In the lower right-hand corner of Table 2, we report weighted least squares estimates, where we explain the employment share of the treatment and the control groups with time and treatment group dummies and their interactions. The estimates in the column entitled 'During-Before' are based on a comparison of employment changes between the treatment and the control group when the minimum wages were reduced in 1993. Similarly, the estimates in the column entitled 'After-During' are based on employment changes that occurred when the minimum wage exceptions were removed in 1995, that is, when the minimum wages increased among the youngest

(C) Blackwell Publishing Ltd/London School of Economics 2009. 


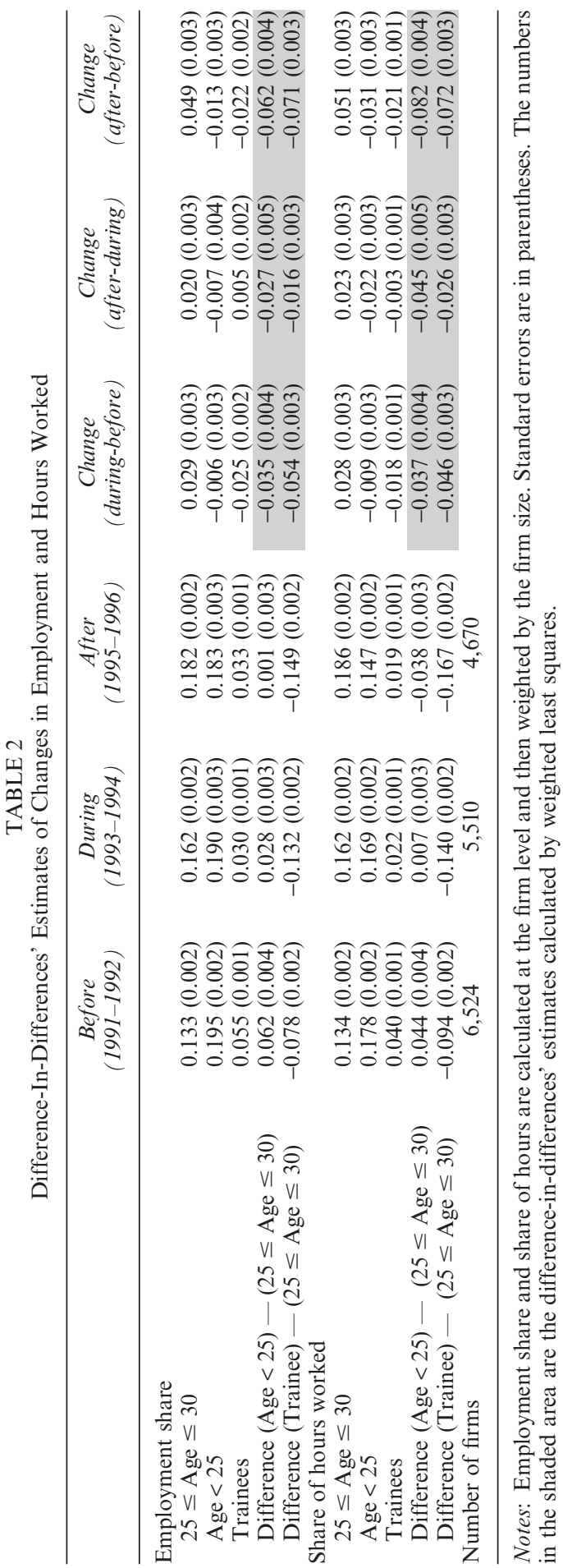

(C) Blackwell Publishing Ltd/London School of Economics 2009. 
workers. Either of these estimates could be interpreted as an effect of minimum wage change and the set-up can be compared with the earlier studies based on minimum wage changes affecting some particular groups (e.g. Card and Krueger 1995; Hyslop and Stillman 2007; Portugal and Cardoso 2006).

Our estimates in the column 'During-Before' reveal that a minimum wage cut seems to imply a decrease in employment in the affected groups. This result does not depend on whether we examine employment shares or the shares of hours worked nor on whether we examine workers below the age of 25 or trainees. The results are perhaps unexpected but would be consistent with the positive employment effects of the minimum wages derived, for example, from a monopsony model.

However, the estimates reported in the column 'After-During' reveal that employment also decreased when the minimum wage exceptions were removed, that is, when the minimum wages increased. Employment in the groups affected by the minimum wage increase decreased by $1.6-4.5$ percentage points more than in the control group, depending on whether we examine the shares of the employed or the hours worked and depending on which treatment group we examine. Given that the wage changes reported in Table 1 were relatively small, this would imply that increases in labour costs have substantial adverse effects on employment.

The contradictory findings are explained by the estimates in the column furthest right where we compare the years 1991-1992 to the years 1995-1996. Apparently, there has been a clear trend: decreasing the employment of both treatment groups occurs simultaneously with the minimum wage changes. However, such trends are hard to detect with only one before-after comparison and the short samples used in some earlier studies, for example, Card and Krueger (1995).

We were somewhat cautious in interpreting the effects of the increase in the minimum wage in 1995 because the minimum wage increase coincided with a change in the date of reporting from August to October. To assess the magnitude of the potential bias due to the seasonal effects we obtained monthly data on employment by age group in the retail trade sector from the Labour Force Survey for the period 1991:1-1996:12. In this data, the share of young workers (aged 15-24) in the retail trade sector is 3.1 percentage points higher in August than in October, while no significant differences are found in the group between 25 and 30 years of age. If we use this difference to adjust our estimates, the effect of the increase of the minimum wage approaches zero.

Table 3 contains results from various robustness checks. To save space, we report only the difference-in-difference estimates for the share of hours worked. First, we try to account for the possible changes in the sample composition by including only the firms that exist for the whole period 1991-1996. We also estimated panel data models with the fixed firm effects to control for unobserved heterogeneity across firms. These changes have only minimal effects on our results. 
TABLE 3

Difference-In-Differences' Estimates of Changes in Hours Worked; Additional Specifications

\begin{tabular}{|c|c|c|c|}
\hline & $\begin{array}{c}\text { Change } \\
\text { (during-before) }\end{array}$ & $\begin{array}{c}\text { Change } \\
\text { (after-during) }\end{array}$ & $\begin{array}{c}\text { Change } \\
\text { (after-before) }\end{array}$ \\
\hline \multicolumn{4}{|l|}{ Continuing firms $1991-1996$} \\
\hline $\begin{array}{l}\text { Difference }(\text { Age }<25)- \\
\quad(25 \leq \text { Age } \leq 30)\end{array}$ & $-0.032(0.006)$ & $-0.046(0.006)$ & $-0.078(0.006)$ \\
\hline $\begin{array}{l}\text { Difference (Trainees) }- \\
\quad(25 \leq \text { Age } \leq 30)\end{array}$ & $-0.041(0.004)$ & $-0.026(0.004)$ & $-0.067(0.004)$ \\
\hline \multicolumn{4}{|l|}{ Fixed firm effects } \\
\hline $\begin{array}{l}\text { Difference }(\text { Age }<25)- \\
\quad(25 \leq \text { Age } \leq 30)\end{array}$ & $-0.037(0.003)$ & $-0.045(0.003)$ & $-0.082(0.003)$ \\
\hline $\begin{array}{l}\text { Difference (Trainees) - } \\
\quad(25 \leq \text { Age } \leq 30)\end{array}$ & $-0.046(0.003)$ & $-0.026(0.003)$ & $-0.072(0.003)$ \\
\hline \multicolumn{4}{|c|}{ Controlling for the unemployment rate interacted with treatment status } \\
\hline $\begin{array}{l}\text { Difference }(\text { Age }<25)- \\
\quad(25 \leq \text { Age } \leq 30)\end{array}$ & $-0.009(0.022)$ & $-0.050(0.012)$ & $-0.060(0.019)$ \\
\hline $\begin{array}{l}\text { Difference (Trainees) }- \\
\quad(25 \leq \text { Age } \leq 30)\end{array}$ & $0.004(0.015)$ & $-0.036(0.008)$ & $-0.032(0.013)$ \\
\hline \multicolumn{4}{|c|}{ Controlling for the real GDP growth rate interacted with treatment status } \\
\hline $\begin{array}{l}\text { Difference }(\text { Age }<25)- \\
\quad(25 \leq \text { Age } \leq 30)\end{array}$ & $-0.001(0.023)$ & $-0.031(0.014)$ & $-0.032(0.030)$ \\
\hline $\begin{array}{l}\text { Difference (Trainees) }- \\
\quad(25 \leq \text { Age } \leq 30)\end{array}$ & $-0.012(0.015)$ & $-0.012(0.010)$ & $-0.025(0.020)$ \\
\hline \multicolumn{4}{|l|}{ New recruits } \\
\hline $\begin{array}{c}\text { Difference }(\text { Age }<25)- \\
(25 \leq \text { Age } \leq 30)\end{array}$ & $0.012(0.011)$ & $-0.052(0.014)$ & $-0.039(0.011)$ \\
\hline $\begin{array}{l}\text { Difference (Trainees) }- \\
\quad(25 \leq \text { Age } \leq 30)\end{array}$ & $-0.212(0.021)$ & $-0.036(0.024)$ & $-0.248(0.022)$ \\
\hline \multicolumn{4}{|c|}{ New recruits aged 24 vs. new recruits aged 26} \\
\hline Difference (Äge 24 - Age 26) & $0.004(0.003)$ & $-0.003(0.004)$ & $0.001(0.004)$ \\
\hline \multicolumn{4}{|c|}{ Aggregate data from the LFS (employment share) } \\
\hline $\begin{array}{l}\text { Difference (Age 15-24) - } \\
\quad \text { (Age 25-30) }\end{array}$ & $-0.046(0.011)$ & $-0.013(0.013)$ & $-0.060(0.012)$ \\
\hline
\end{tabular}

Notes: Standard errors in parentheses. Entries are difference-in-differences' estimates calculated by weighted least squares.

A more serious concern is that the treatment and the control groups might be differentially affected by the changes in the business cycle. Also the subminimum wage policy may have been an endogenous response aiming to alleviate the unemployment problem among the groups that suffered most from the recession. As shown by Besley and Case (2000), both of these factors might cause a bias in the estimates. We tried to account for these problems by adding business cycle indicators and their interactions with the treatment group status to the model. We experimented with several possible indicators and report in Table 3 results of including either the unemployment rate or the growth rate of real GDP. Including the unemployment rate interacted with the treatment group status reduces the estimate for the introduction of the subminimum wage policy, but does not affect the estimate for removing it. Controlling for the GDP growth rate, in the same way reduces all estimates so that after accounting for the change in the reporting date in 1995, all estimates are very close to zero. 
Another way to minimize the problem of potentially different trends is to make the treatment and the control groups more similar by using tighter definitions. In Table 3, we report results where we first restrict the data to new recruits (who were not in the data in the previous year though their employer was) and then gradually narrow the age range. We report the results that compare 24-year-olds with 26-year-olds. Here, the point estimates indicate a slight increase in employment when the minimum wages are cut and an equally small decrease when they are increased with no signs of group-specific trends over the whole period. However, the estimates are very small and they are clearly not statistically significant. Experiments restricting the treatment group to those with, at most, one year's recorded experience did not alter our conclusions.

As a final check, we attempt to deal with the change in the date of reporting by using the monthly data on employment from the Labour Force Survey. We use time-series data of employment by age group in the retail trade sector between 1991:1 and 1996:12 and explain the share of workers aged between 15 and 24, using the share of workers aged between 25 and 30 as a control group. We add indicators for month and year to the model and define the minimum wage exception period for the months between July 1993 and June 1995. The estimates reported in the table are coefficients of the interaction terms between the treatment group and the changes in the minimum wage policy. The estimates for the effect of the introduction of the youth minimum wage policy turn out to be close to the employment effects reported for those under 25 in Table 2. On the other hand, we find no changes in the relative employment shares when the minimum wage exceptions were removed in 1995, indicating that the negative estimates in Table 2 were due to the seasonal effects.

Of the specifications reported in Table 3, we would prefer the comparison of tightly defined groups (24-year-olds vs. 26-year-olds) or the specification that includes real GDP growth interacted with the treatment group status both adjusted for the seasonal effects. These specifications do not reveal different trends in the treatment and the control groups. Based on either of these results, we conclude that the changes in youth minimum wages had no statistically or economically significant employment effects. This is naturally consistent with the fact that we do not observe substantial wage effects.

\section{Conclusions}

At first sight, our finding that youth subminimum wages had only a small effect on wages and no clear effect on employment are somewhat surprising, given the prevailing macroeconomic situation. According to the Labour Force Survey, the unemployment rate was 31 per cent for workers aged 20-24 in 1994 and the excess supply of labour should have made it easy to attract workers even with low wages. One explanation for not finding significant effects is that, even in times of high unemployment, employers were not

(C) Blackwell Publishing Ltd/London School of Economics 2009. 
willing to pay less than the old minimum, fearing that paying less than a fair wage would have adverse effects on effort. Experimental evidence supports this reasoning (Falk et al. 2006). Furthermore, the Finnish findings are consistent with Katz and Krueger (1992), who noted the low utilization of subminimum wages in a situation where employers could have paid less than the minimum rate. In particular, it may be difficult for firms to justify the payment of different wages for the same work to workers of different ages. Then a temporary reduction in the minimum wages for the youngest workers does not cause significant changes in actual wages. This does not rule out the possibility that the reduction in the minimum wages across the board or a more permanent reduction in minimum wages would not have any effects.

The broader methodological lesson of this paper concerns pre-existing trends in employment of the groups affected by the minimum wage change. In the Finnish case, one could easily get different estimates by analysing the effects of a minimum wage cut instead of analysing the subsequent minimum wage increase. These contradictory findings seem to be due to pre-existing trends in employment, but such trends would be hard to detect with short panels and a simple before-after comparison often used in evaluating the effects of a minimum wage change.

Final version accepted on 18 December 2008.

\section{Acknowledgements}

This study is funded by the Finnish Work Environment Fund. We are grateful to Timo Reinikainen and Katja Veirto from Service Union United for providing information about the details of collective agreements in the retail trade sector, Eija Ahopelto from the Confederation of Finnish Industries for help with payroll record data and Per Skedinger, Jari Vainiomäki and two anonymous referees for their valuable comments. An earlier version of this paper was presented at the BJIR seminar '100 years of Minimum Wage Regulation'. Paul A. Dillingham has kindly checked the English language. The usual disclaimer applies.

\section{Notes}

1. There is a tendency in Finland for temporary policy changes to become permanent. Therefore, it was not ex ante evident that the policy change regarding the minimum wages of young workers would remain temporary.

2. We use data from 1991 instead of 1990 because the wage increases agreed in the 1990 contract raised the minimum wages from 1 October 1990. The year 1990 was also the first year when the payroll record data was gathered and may contain more errors.

3. Jones et al. (2006) note the same pattern by using the data from a Finnish retail firm. 
4. We do not include the year 1995 in the years of minimum wage exceptions, because the exceptions ended on 15 June 1995 and the payroll record data for the year 1995 was gathered from the firms in October.

5. In the union contract the minimum wage exceptions were restricted to those aged below 25 who had, at most, one year's work experience. The treatment group in our baseline estimates consists of those aged below 25 that have, at most, two years' recorded work experience. There are two reasons for this. First, according to the Confederation of Finnish Industries, responsible for data gathering, the classification of experience in the payroll record data is not fully accurate. Second, the wording of the union agreement is fairly complicated and it may not be obvious for all employers that the exceptions do not apply to those with more than one year of experience, particularly when the experience is from another firm. A looser definition of the treatment group that we use in the paper is a compromise between a tight definition that might exclude some treatment group members and even looser definition that would include all below 25 in the treatment group. Our choice may of course contain some classification errors. We have analysed the robustness of the results in this respect, as discussed later.

6. These results and various other robustness checks are reported in our working paper version.

\section{References}

Besley, T. and Case, A. (2000). 'Unnatural experiments? Estimating the incidence of endogenous policies'. Economic Journal, 110: F672-94.

Böckerman, P. and Uusitalo, R. (2006). 'Erosion of the Ghent system and union membership decline: lessons from Finland'. British Journal of Industrial Relations, 44: 283-303.

Brown, C., Gilroy, C. and Kohen, A. (1982). 'The effect of the minimum wage on employment and unemployment'. Journal of Economic Literature, 20: 487528.

Card, D. and Krueger, A. (1995). Myth and Measurement: the New Economics of the Minimum Wage. Princeton, NJ: Princeton University Press.

Dickens, W. T., Goette, L., Groshen, E. L., Holden, S., Messina, J., Schweitzer, M. E., Turunen, J. and Ward, M. E. (2007). 'How wages change: micro evidence from the International Wage Flexibility Project'. Journal of Economic Perspectives, 21: $195-214$.

Dolado, J., Kramarz, F., Machin, S., Manning, A., Margolis, D. and Teuling, C. (1996). 'The economic impact of minimum wages in Europe'. Economic Policy, 23: 317-72.

Eurofound (2007). Minimum Wages in Europe. Dublin: European Foundation for the Improvement of Living and Working Conditions.

Falk, A., Fehr, E. and Zehnder, C. (2006). 'Fairness perceptions and reservation wages - the behavioral effects of minimum wage laws'. The Quarterly Journal of Economics, 121: 1347-81.

Honkapohja, S. and Koskela, E. (1999). 'The economic crisis of the 1990s in Finland'. Economic Policy, 14: 400-36.

Hyslop, D. and Stillman, S. (2007). 'Youth minimum wage reform and the labour market in New Zealand'. Labour Economics, 14: 201-30.

(C) Blackwell Publishing Ltd/London School of Economics 2009. 


\section{British Journal of Industrial Relations}

Ilmakunnas, P. and Maliranta, M. (2003). 'The turnover of jobs and workers in a deep recession: evidence from the Finnish business sector'. International Journal of Manpower, 24: 216-46.

Jones, D. C., Kalmi, P. and Kauhanen, A. (2006). 'How Does Employee Involvement Stack Up? The Effects of Human Resource Management Policies on Performance in a Retail Firm'. Working Paper No. 3, ILR Collection, Cornell University.

Katz, L. F. and Krueger, A. B. (1992). 'The effect of the minimum wage on the fast-food industry'. Industrial and Labor Relations Review, 46: 6-21.

Layard, R. and Nickell, S. (1999). 'Labor market institutions and economic performance'. In O. Ashenfelter and D. Card (eds.), Handbook of Labor Economics, Vol. 3C. Amsterdam: North-Holland, pp. 3029-84.

Lehtonen, V.-M., Puustinen, T. and Tuominen, P. (1983). 'Vuoden 1980 kalleustutkimus'. Statistics Finland, Studies No. 87.

Neumark, D. and Wascher, W. (2007). 'Minimum wages and employment'. Foundations and Trends in Microeconomics, 3: 1-182.

OECD (2006a). OECD Economic Surveys: Finland. Paris: OECD. (2006b). Employment Outlook. Paris: OECD.

Portugal, P. and Cardoso, A. R. (2006). 'Disentangling the minimum wage puzzle: an analysis of worker accessions and separations'. Journal of the European Economic Association, 4: 988-1013.

Saari, E. (1996). 'Joustoilla työtä? Työsopimuslain poikkeus ja sopimus nuorten työllistymisedellytysten parantamiseksi - helpottuiko pitkäaikaistyöttömien ja nuorten työhön pääsy?' Työpoliittinen tutkimus No. 139. Ministry of Labour: Helsinki.

Sauramo, P. and Solttila, H. (1985). 'Minimipalkat ja nuorisotyöttömyys Suomessa 1965-1981'. Finnish Economic Journal, 81: 384-94.

Skedinger, P. (2006). 'Minimum wages and employment in Swedish hotels and restaurants'. Labour Economics, 13: 259-90.

(2008). 'Sweden: A Minimum Wage Model in Need of Modification?' IFN Working Paper No. 774, Research Institute of Industrial Economics.

Stewart, M. B. and Swaffield, J. K. (2002). 'Using the BHPS wave 9 additional questions to evaluate the impact of the national minimum wage'. Oxford Bulletin of Economics and Statistics, 64: 633-52. 


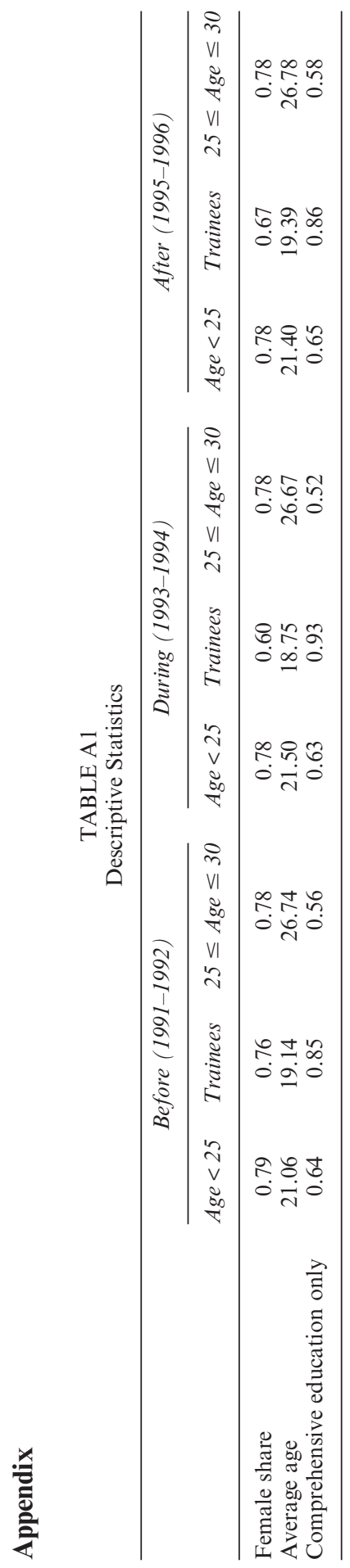

